\title{
INSTITUTIONAL EDUCATION FOR CHILDREN AND ADOLESCENTS WITH RISKY BEHAVIOUR
}

\author{
Miluše Hutyrová \\ Palacky University Olomouc, Czech Republic
}

\begin{abstract}
In the Czech Republic, the model of life in schools for institutional education is structured. The main of focus of the article is to map diverse approaches of various professionals to the current process of transformation of Czech system of care of children at risk and to search for a feasible solution of the situation. The children are taken care of, in particular, from the material perspective since these schools' level corresponds to the level of a middle-income family. The institution's role ends upon the achievement of child's adulthood or upon the completion of his/her education, and it is then solely up to the young individual to cope with life outside the institution on his/her own. A young individual leaving an institutional education facility should be able to manage various social skills, in particular, when it comes to activities relating to self-management and housekeeping.
\end{abstract}

Key words: institucional education, children, adolescent, risky behaviour, problematic behaviour, behavioural disorder.

\section{Introduction to the Issue}

The system of care for individuals with psychosocial risk and disorder in the Czech Republic is being subjected to numerous essential reforms, the need for which is indisputable. Currently, it is a system characterized by significant departmental fragmentation, a high number of actors, oftentimes unclear rules, and numerous financial resources. It is ruled by many stereotypes, deep-rooted procedures, and prejudices. This system is often the subject of criticism on the part of professional and non-professional public at both national and international levels (Večerka et al., 2009). The main of focus of the article is to map diverse approaches of various professionals to the current process of transformation of Czech system of care of children at risk and to search for a feasible solution of the situation. Professionals from various resorts still much differ in their opinions, the overall approach to relevant problems lacks unity and, so far, not enough quality research has been conducted.

It is obvious that the reform is about to constitute a long-term process the anticipated results of which may only be obtained in several years. There is a clear need for a national strategy at governmental level. A lot of documents, from whichthis strategy may stem, exist. Particularly, it is possible to rely on the large amount of research and analyses describing the state of the given problem (for example, the Analysis of the Efficient Functioning of the System of Care of Children at Risk). Strongly alarming and warning practical knowledge can be noticed in many cases. On the other hand, there is a great deal of good practise examples (for example, the creation of a network of social activities related to the Timely Intervention System).

Regarding the basic principles, the newly created national strategy may also rely on the principles of protection of children's rights, ensuing from the 
international commitments of the Czech Republic, the judgments of the European Court of Human Rights, the opinion of the Supreme Court on the issue of ordering institutional education for children for socioeconomic reasons, etc. In this respect, it is also possible to incorporate the amendment to the Act on Children's Social-legal Protection effective as of 01 January 2013 and the proposal for a new Civil Code. The reform is inspired by the National Action Plan for 2009-2011 created for the purpose of transforming and unifying the system of care of children at risk. The amendment to the Act on Children's Social-legal Protection (effective as of 01 January 2013), which should be one of the first outputs of the reform, defines the conditions for creating a network of services for working with families and the standard activities pursued by the social-legal protection bodies. The amendment also deals with the development of substitute family care, the enhancement of foster care, the material support of foster care for a transitional period, and the creation of the conditions for the provision of supporting and relieving services for both new and existing foster families.

The basic goals of the national strategy include unification of the system, the overcoming of the departmental fragmentation, the shifting of the focus of work to prevention and supporting services, and the creation of a system of follow-up and related services and care. The re-directing of financial, material and personnel resources should also be part of these changes.

\section{Placement of Children in Institutional Education Schools}

In the Czech Republic, a certain number of young individuals leaving institutional education schools start their independent lives every year. Some of them may find themselves in another, state-operated facility within a few years. Frequently, the whole system of state care of children at risk is put to blame. The research and analysis carried out in this respect refer to the fact that in most cases, children's long-term institutional care negatively affects their everyday lives. Despite thegood quality of the care, these facilities are not able to prepare young people for their day-to-day life with all the rights, duties, pleasures and worries. This situation was confirmed by both the research 'Rights and Needs of Young People Leaving Children's Houses' carried out by the Centre for Substitute Family Care (Kovařík, J., Bubleová, V., Šlesingerová, K.) in 2004 and the 'Analysis of the Efficient Functioning of the System of Care of Children at Risk' carried out by the Division for Crime Prevention of the Ministry of Interior of the Czech Republic (Gjuričová, J.) in 2007. These studies, which were implemented based on a different methodology (and the conclusions of which are polemical), refer to the fact that the Czech Republic has no clearly defined, interlinked and, in particular, functional system of follow-up care concerning young people leaving institutional education facilities.

Follow-up or post-institutional care is much more in the interest of non-profit organizations that have already prepared and published materials stemming from 
field analyses and research. These materials focus on finding the reasons for the high number of children placed in institutional education facilities and look for methods of avoiding long-term removal of children from their primary families (the amendment to Act No. 359/1999 Coll., effective as of 01 January 2013). These organizations have practical experience in organizing projects helping young people to live quality independent life after leaving the institutional facility.

As stated by Gjuričová (2008) in the Analysis of the Efficient Functioning of the System of Care of Children at Risk, the children placed in institutional education facilities can be divided into four groups:

- orphan children with no mother and no father; their number is minimal;

- children who exhibit criminal behaviour and in relation to whom there is justified concern that their criminal behaviour will continue;

- children with psychosocial risk, who come from a socially weak and disorganized family environment where their upbringing was jeopardized, to a major extent, by neglect, abuse, torture or other socially pathological effects;

- children exhibiting risky and problematic behaviour, that is, children suffering from behavioural disorders (truancy, experiments with addictive substances, etc.).

The provision of substitute institutional care for children and youths in the Czech Republic is regulated, in particular, by Act No. 109/2002 Coll. the amendment to which has been applicable since 01 January 2013. Substitute education care means institutional education and protective education and care for children needing immediate help.

However, the term 'institutional education' is misleading. It is definitely not a synonym to substitute family care, but only to institutional family care (Škoviera, 2007). The international translation of the term institution is die Institution in German, institution in French, institutoin Spanish, institutoin Italian, and institutin Russian. The Ministry of Education, Youth and Sports of the Czech Republic uses the collocation 'institutional education' as the primary definition of the system of substitute education. Since 01 January 2014, the placement of children in respective facilities has been implemented pursuant to Act No. 89/2012 (Civil Code).

Facilities providing substitute institutional education are divided by the Ministry of Education, Youth and Sports of the Czech Republic into the following categories:

- diagnostic institutes,

- children's homes,

- children's homes with a school,

- educational institutes. 
Diagnostic institutes provide professional support for children's homes, children's homes with a school, and educational institutes and, in particular, diagnose children subject to institutional education. The capacity of children's homes, children's homes with a school and educational institutes is about 30 up to 40 children divided into groups of 6 up to 8 children. In the facilities, small accommodation units (flats, houses) or the central house and separated accommodation premises are preferred.

\section{Transformation of Institutional Education Facilities}

The current functioning of the system of care of children at risk raises concerns about its efficiency. In the international context, the Czech Republic is rebuked for having a high number of children placed in institutional care facilities. In 2010, approximately 6,500 children were placed in 220 facilities (14 diagnostic institutes, 151 children's homes, 27 children's homes with a school, and 28 educational institutes).

More than a half of these children stay in the stated facilities until their legal age. The long-term placement in institutional education facilities has several reasons:

- the endeavour on the part of social-legal protection bodies, courts and the managements of the facilities where a child is placed to preserve the relatively satisfactory state of his/her current situation, which applies, in particular, to children coming from a socially weak and disorganized family environment;

- the endeavour on the part of the institutes' managements to ensure completion of the child's mandatory school attendance or his/her preparation for his/her future job that the child would most likely not be able to complete in his/her family (Gjuričová, 2008).

The stated situation has resulted in the not yetsufficiently elaborated system of timely intervention enabling work with both the child and his/her family in the early stages of the given problem. Working with the families of the children placed in institutional education facilities is also exceptional and the goal of such work should be to return the child to his/her family as quickly as possible. Oftentimes, the placement of a child in institutional care only means interrupting his/her social pathological development that continues when the child leaves the institute or that only arises as a consequence of unsuitable conditions in the environment to which he/she returns.

Social-legal protection workers are crucial in the care of children at risk. However, they are negatively affected by being overburdened with administrative tasks, by the missing supervision and methodological leadership and, in particular, by their shortage.

With regard to the stated facts, the Czech Republic seems to be determined to deal with this situation. The National Strategy of Protection of Children's Rights 
(approved by the Government Resolution No. 4 of 04 January 2012) was created and showed that by 2018, the individual departments would have created a functional system ensuring protection of children's all rights and the due fulfilment of their needs.

The Action Plan for fulfilling the National Strategy of Protection of Children's Rights (approved by the Government Resolution No. 258 of 11 April 2012) sets the tasks for 2012-2015 and its main goal is to enhance the quality of the system of protection of children's rights and the care of children at risk.

\section{Research}

We carried out a research primarily focused on post-institutional care of children leaving institutional education facilities. Twelve interviews were implemented from April to June 2013 with institutional education facility workers, that is, workers from children's homes with a school and educational institutes.

The goals of the research were as follows:

- to define and characterize the offer and utilization of follow-up care in institutional education facilities - half-way homes, recovery centres, supporting programmes (for example, hostels, 'start-up flats');

- to specify the adolescents' and young adults' possibilities when leaving the institution (follow-up care, family, relationships, recreational activities, accommodation, etc.) and their chances to find employment;

- to compare data obtained from the respondents in institutional education schools and social services facilities

The last part of the interview was devoted to the current issue relating to the transformation of care of children at risk in the Czech Republic, that is, more precisely, the transformation of institutional education schools, and to the workers', leading workers' and clients' needs. The results of this part that documents the opinions of workers (special educators, psychologists, social workers, and teachers) on the process of transformation of the system are stated.

\section{Results}

\section{What would be your first step within the transformation of the system of institutional education?}

Four out of the 7 respondents who answered this question stated that they would like to work with the clients' families. For example, respondent No. 8 referred to the "family's involvement in the re-socialization, for example, in the form of a family therapy..." One respondent (No. 6) stated that he would "divide the clients thoroughly based on quality diagnosis". Other respondents would try to separate facilities for children subject to institutional education from facilities for children subject to protective education. A unique opinion was expressed by respondent No. 12 who would promote the actual unification of the system. 


\section{What would you eschew within the transformation of the system of institutional education?}

This question was answered by 7 respondents. All answers were original, in essence. Only two respondents agreed that within the transformation of the system of institutional education, they would definitely eschew workers' unprofessionalism. This opinion is close to the answer provided by respondent No. 1 who stated that he would like to eschew "changes made without consulting practising professionals..." Other respondents presented original opinions which, however, were isolated. For example, respondent No. 7 believes that "children placed in the facilities have too much freedom and would need more scheduled events". Respondent No. 6 stated that he would eschew the "abolition of institutional education", and respondent No. 8 thinks that "due to the lack of children, educational institutes admit all of them" and that "he would eschew the inclusion of children with other diagnoses, for example, children with mental retardation or psychiatric diagnoses or youths who have been imprisoned".

3. Which needs do you consider as the most important from the perspective of the facility's director?

This question was answered only by 5 respondents, 3 of whom agreed that qualified personnel were the most important. There also appeared some isolated opinions. Respondent No. 9 thinks that "the director's extended competencies guaranteed by the laws" are the most important, while respondent No. 11 believes that "deeper cooperation with social-legal protection workers when children are leaving the respective facility" is necessary.

4. Which needs do you consider as the most important from the client's perspective?

None of the total number of the 6 respondents who answered this question provided identical or similar answers. All answers were original, and even where various items were expressed, they could be unified into one group reflecting the clients' overall needs, being safe environment, help in the return from the facility to family, adults' respect, interest in the client as a person, background, close person, family, holiday, apprenticeship certificate, and the need for education and employment.

5. Which needs do you consider as the most important from the perspective of a facility's professional worker?

This question was answered by 7 respondents, 2 of whom concurred in their statements. Respondents No. 6 and 8 believe that it is necessary to have " $a$ functioning team willing to work on their professional growth, interested in the given issue, and realizing the sense and hope in what they do" and "cooperating colleagues pursuing, in essence, the same goals". Two respondents consider as necessary the follow-up care provided by professionals and "the satisfaction of client's needs in the respective facility and within the follow-up (after treatment) care". Other statements expressthe respondents' original opinions. For example, 
respondent No. 9 considers as the most important "protection on the part of the employer", respondent No. 7 "the setting of rules for all workers and their thorough observance and promotion", and respondent No. 11 believes that it is necessary to "listen to the professionals when the laws are created".

\section{What would you expect of a follow-upcare facility?}

This question was answered by 12 respondents. Their statements were relatively isolated, and not more than two respondents always concurred. Some statements contradicted themselves. For example, respondent No. 5 stated "satisfaction with the cooperation". Conversely, respondent No. 6 "would like the cooperation to be closer". Two respondents would like that "clients be placed in the respective facilities" and respondents No. 10 and 12 considered "the availability and professionalism" as necessary. An interesting opinion was expressed by respondent No. 8 who would expect that follow-up care be "the opportunity for clients to try 'mock life",. Another interesting opinion was expressed by respondent No. 7 who would expect the follow-up care facility "to keep in touch with the education institutes (we know nothing about our children), to contact the clients leaving the education facility (only a few clients keep in touch), and to enable former clients' presentations - experience sharing". The answers also stated the need for a higher number of these facilities, a system of accommodation, help in finding a job, and contact with the institutions.

\section{What would you add?}

Four out of the total number of 12 respondents took advantage of the possibility of expressing their additional ideas. Their statements varied. For example, respondent No. 8 had a specific requirement for a more detailed elaboration of the issue of the abuse of THC by minor individuals and expressed his idea of how to work with such phenomena. He stated that "the use of THC comes to become standard in the category of 15- up to 18-year old individuals". Respondent No. 5 realized the following fact: "In the last years, it has been the society's endeavour to help these children. Half-way homes have been built, help has been offered by associations and money has been raised through charities. Moreover, children have no established basic habits, predominantly working." Contradictory statements were provided by 2 respondents. Respondent No. 7 wished "more optimism in working with children and their families", while respondent No. 6 referred to "clients difficult to deal with, Romany clients, or detention institutes".

\section{Summary}

- In the last group of questions, we were interested to know the respondents' (facility workers') opinions on the current transformation of the system of institutional education facilities. Their opinions differed considerably and no general conclusion can be deduced from them. 
- However, we can use them as inspiration for our next research.

\section{Interpretation and Recommendations}

The respondents, being institutional education facility workers, had difficulty in formulating their answers. They also referred to the significant dissimilarity of the individual young people leaving institutional education facilities, such dissimilarity lying in different family background, personality traits, and motivation for change. The answers reflected the respondents' living and working experience.

It was difficult for staff members of educational facilities to formulate answers clearly. They emphasised great variety of individual young people who are leaving the facilities for the provision of institutional education. This variety is manifested in their behaviour, family setting, personal characteristics and motivation for change. In the responses there was a clear influence of life and work experience, subjective motivation of staff members was accentuated, such as relationship towards a concrete young person or event etc. It could not be overlooked that majority of respondents from the category of staff members of educational facilities were not concerned by the clients' relationships and connected emotions. They were quite sceptic about long-term family, partner or friendly relationships of the clients. A question arises here, how is it possible under the conditions of educational facilities for the provision of institutional education to penetrate into the inner world of the clients. There are many discrepancies, the clients are not in the facilities voluntarily, are taken away from their natural social environment that in most cases showed signs of social pathology, parents were not able to ensure basic care, their relationship bonds were impaired but despite all this in many cases they desire to return to these family settings after completing institutional education.

The result analysis stemming from the interviews with respondents (institutional education facility workers) refers to the difficulty in generalizing their experience, that is, in formulating their recommendations. It must be pointed out that the conducted examination was some kind of a pre-research in which the authors wanted to verify the tools and the methods of work. Furthermore, the pre-research was participated by a relatively small number of respondents -12 .

\section{Conclusion}

An interesting fact is that the Action Plan for fulfilling the National Strategy of Protection of Children's Rights, which was approved by the Government Resolution No. 258 of 11 April 2012, sets the tasks for 2012-2015 and its goal is to enhance the quality of the system of protection of children's rights and the care of children at risk. At present, the institutional education facilities are being subject to transformation, which was also reflected in the implemented research 
(uncertainty with respect to the future and defensive tendencies in some workers).

The visions of the transformation of institutional education facilities are as follows:

- to accentuate preventive education care;

- to limit the scope of institutional education and emphasize the development of outpatient care;

- to transform the existing institutes into highly specialized workplaces providing various forms of prevention of children's risky behaviour; this vision presumes partial change in the role of these facilities;

- to create a cost-saving, efficient and available system of professional care for children at risk and their families;

- to ensure interdepartmental and inter-domain cooperation in the system of institutional care and, in particular, in the care of minors and young adults leaving institutional care, with the aim to reducing recidivism, that is, follow-up care.

The concept draft counts on closer cooperation with the families (in the form of outpatient care) and newly anticipates closer cooperation with foster parents who care for children at risk. The facilities could provide support for families, for example, in the form of education, consultancy or family therapy. Some of the proposed changes were also stated in our research.

\section{References}

1. Gjuričová, J. (2008). Analýza efektivity fungování systému péče o ohrožené děti. Veřejná správa, Praha, Ministerstvo vnitra ČR, č. 26-27.

2. Hort, V. a kol. (2000). Dětská a adolescentní psychiatrie. Praha, Portál.

3. Jucovičová, D., Žáčková, H. (2010). Neklidné a nesoustředěné ditě ve škole a v rodině. Praha, Portál.

4. Labáth, V. (2001). Riziková mládež. Praha, Sociologické nakladatelství.

5. Liabo, K., Richardson, J. (2007). Conduct Disorder and Offending Behaviour in Young People. London, Jessica Kingsley Publishers.

6. Lechta, V. (2010). Základy inkluzivni pedagogiky. Praha, Portál.

7. Matoušek, O., Kroftová, A. (2003). Mládež a delikvence. Praha, Portál.

8. Michalová, Z. (2007). Sonda do problematiky specifických poruch chování. Havlíčkův Brod, Tobiášs.

9. Miovský, M. (2006). Kvalitativní př́stup a metody v psychologickém výzkumu. Praha, Grada Publishing.

10. O'Reilly, D. (2005). Conduct Disorder and behavioural Parent Training. London, Jessica Kingsley Publishers.

11. Paclt, I. a kol. (2007). Hyperkinetické poruchy a poruchy chování. Praha, Grada Publishing.

12. Hadj Moussová, Z. a kol. (2005). Pedagogicko-psychologické poradenství I. Vybrané problémy. Praha, Univerzita Karlova v Praze, Pedagogická fakulta.

13. Richter, K., Hutyrová, M. a kol. (2012). Co s tím mám dělat. Olomouc, Magistrát Města Olomouce.

14. Říčan, P. a kol. (2006). Dětská klinická psychologie. Praha, Grada Publishing. 
Proceeding of the International Scientifical Conference May $23^{\text {th }}-24^{\text {th }}, 2014$ Volume III

15. Selikowitz, M. (2009). ADHD. Oxford, Oxford University Press.

16. Škoviera, A. (2007). Dilemata náhradní výchovy. Praha, Portál.

17. Večerka, K. (2009). Mládež v kriminologické perspektivě. Praha, Institut pro kriminologii a sociální prevenci. 